\begin{tabular}{|c|c|c|c|}
\hline Article Info & \multicolumn{2}{|c|}{\begin{tabular}{l|l} 
RESEARCH ARTICLE & ARAŞTIRMA MAKALESİ \\
\end{tabular}} & \\
\hline Title of Article & \multicolumn{2}{|c|}{$\begin{array}{c}\text { Landscape Design for Architects - } \\
\text { Teaching Landscape Design in } \\
\text { Architecture }\end{array}$} & \\
\hline $\begin{array}{l}\text { Corresponding } \\
\text { Author }\end{array}$ & \multicolumn{2}{|c|}{$\begin{array}{l}\text { Yıldız AKSOY/ İstanbul Medeniyet Üniversitesi Sanat Tasarım ve Mimarlık Fakültesi, } \\
\text { Şehir ve Bölge Planlama Bölümü, yildiz.aksoy@ medeniyet.edu.tr }\end{array}$} & \\
\hline $\begin{array}{l}\text { Received Date } \\
\text { Accepted Date }\end{array}$ & \multicolumn{2}{|l|}{$\begin{array}{l}18.10 .2020 \\
11.11 .2020\end{array}$} & \\
\hline Author / Authors & Yıldız AKSOY & ORCID: 0000-0002-8804-8337 & \\
\hline How to Cite & \multicolumn{2}{|c|}{$\begin{array}{l}\text { Aksoy, Y. (2020). Mimarlar İçin Peyzaj Tasarımı - Mimaride Peyzaj Tasarımının } \\
\text { Öğretilmesi, Kent Akademisi, Volume, } 13 \text { (43), Issue 4, Pages, 628-639 }\end{array}$} & $\begin{array}{l}\text { Kent Akademisi } \\
\text { Urban Academy }\end{array}$ \\
\hline
\end{tabular}

\title{
Mimarlar İçin Peyzaj Tasarımı - Mimaride Peyzaj Tasarımının Öğretilmesi
}

\begin{abstract}
:
How much Landscape Design is needed for the education of Architects and Urban Planners? Landscape architects specialize in landscape design and planning. When the course curriculum of Architecture and Urbanism programs are examined, it is seen that the courses on Landscape Design and Landscape Architecture are almost non-existent. It limits the ability of architects and city planners to understand the complex relationships between buildings and their immediate surroundings, landscapes and the environment. In this research, a survey was conducted with 85 students who took the "Landscape Design in Architecture" course, which is given in the Department of Architecture of YTU Faculty of Architecture. It is aimed to reveal the ideas of the students who take the Landscape Design in Architecture course about the course and also the contribution of the course to architectural education. Likert method was used to evaluate closed-ended questions. Open-ended questions had been read and analyzed one by one. The survey questions were analyzed using the SPSS program.
\end{abstract}

KEYWORDS: Architecture, education, landscape design

\section{ÖZ:}

Mimarların ve Şehir Plancılarının eğitimi için ne kadar Peyzaj Tasarımı bilgisine ihtiyaç vardır? Peyzaj mimarları peyzaj tasarım ve planlamasında uzmanlaşmışlardır. Mimarlık ve Şehircilik programlarının ders müfredatları

${ }^{1}$ Istanbul Medeniyet University, Faculty of Art, Design and Architecture, Urban and Regional Planning Department,yildiz.aksoy@medeniyet.edu.tr 
incelendiği zaman Peyzaj tasarımı ve Peyzaj Mimarlığına yönelik derslerin yok denecek kadar az olduğu görülmektedir. $\mathrm{Bu}$ durum, mimarların ve şehir plancılarının, binalar ile yakın çevrelerini, peyzajları ve çevre arasındaki karmaşık ilişkileri anlama yeterliliğini sınırlandırmaktadır. Bu araştırmada YTU Mimarlık Fakültesi Mimarlık bölümünde verilmekte olan "Mimarlıkta Peyzaj Tasarımı" dersini alan 85 öğrenci ile anket çalışması yapılmıştır. Öğrencilerin ders hakkındaki fikirlerini ve aynı zamanda da dersin mimarlık eğitimlerine olan katkısını ortaya koymak amaçlanmıştır. Kapalı uçlu soruların değerlendirilmesinde likert yöntemi kullanılmıştır. Açık uçlu sorular tek tek okunarak analiz edilmiştir. Anket sorularının değerlendirilmesinde SPSS programı kullanılmıştır.

ANAHTAR KELIMELER: Mimarlık, eğitim, peyzaj tasarımı.

\section{"Mimarlar İçin Peyzaj Tasarımı - Mimaride Peyzaj Tasarımının Öğretilmesi”}

\section{GİRIŞ̧}

Mimari ve peyzajın bütünleşmesi mekânsal olarak farklı şekillerde anlaşılabilir ve yorumlanabilir. Mimarlık ve Peyzaj Mimarlığı disiplinleri arasındaki ayrım birçok yönden sorgulanmaktadır.

Austerlitz ve diğ., (2002), mimarlık ve peyzaj mimarlığı eğitiminin ekseni olan tasarım stüdyosunun diğer mesleklerde gelecekteki eğitim için paradigmatik bir model olarak görüldüğüne inanmaktadır. Bu nedenle, onu iyice anlamak, mesleki düşüncelerin çok ötesinde değerli olabilir. Mevcut araştırmalar, stüdyonun karmaşık ve belirsiz doğası hakkında, mimari tasarım problemlerinin ve yaratıcı sürecin doğasında var olan benzersizlik nedeniyle yoğunlaşan kanttlar sunar.

Modern dönem boyunca ortaya çıktığı şekliyle tasarım stüdyosu, mimarlık okullarının çoğunda mimarlar, peyzaj mimarları ve tasarımcılar için eğitimin odak noktası haline gelmiştir (Boyer ve Mitgang, 1996). Peyzaj mimarlı̆̆ının kendi modern tarihi anlayışı son on yılda büyüdükçe, artan bir mimari literatür hacmi, Mies Vander Rohe, Richard Neutra, Rudolf Schindler ve Frank Lloyd Wright gibi mimarların uygulamalarını peyzaj mimarlığı terimleriyle tanımlamaya çalışmışlardır. Walter Gropius'un söylemde belirgin bir şekilde yokluğu, evindeki çalışmanın çağdaşlarının çalışmaları arasında nadir görülen bir mimariyi peyzajla ilişkilendirme stratejisini temsil ettiği göz önüne alındığında özellikle önemlidir (Kent, 1997).

Mimarlık dar anlamda yapı tasarlama sanatı geniş anlamda ise doğal ve fiziksel mekânların gelecek neslin ihtiyaçlarını karşılayacak biçimde peyzaj tasarım ve planlamasının yapılmasıdır (Gül, 2015). Peyzaj mimarlı̆̆ı, zaman ve mekândaki peyzajların bütünsel bilgisini ve anlayışını geliştirmeyi amaçladığından, Peyzaj Mimarlığı dersleri, mimarların ve şehir planlamacılarının eğitimi için çok önemlidir (Bruns ve diğ., 2010). Peyzaj mimarlığı karmaşık ve disiplinler arası bir meslektir (Gazvoda, 2002) ve bahçecilik bilgisinin yanı sıra mühendisliğin yaratıcı uygulamasını içerir.

Peyzajın önemli bir kullanımı, yaşam için fiziksel bir "mekân", aynı zamanda toplumsal kimliğe anlam ve katkıları ile bir "yer" olmasıdır (Hunziker ve diğ., 2007).

Peyzajların çok yönlü doğası ve insanlığın onlarla etkileşimi, Peyzaj Mimarisini büyük kapsamlı bir konu alanı haline getirmektedir (Fetzer, 2014). Profesyonel bir faaliyet alanı ve akademik bir disiplin olarak Peyzaj Mimarlı̆̆ ölçeklerdeki peyzajların şekillendirilmesiyle ilgilenir (Bruns ve diğ., 2010).

Bu araştırmada YTÜ Mimarlık Fakültesi Mimarlık Bölümünde verilen Mimarlıkta Peyzaj Tasarımı dersinin öğrencilerin mimari projelerinin okunurluğu açısından ne kadar önemli olup olmadığı, Peyzaj Tasarımı dersinin mimari projelerine katkı sağlayıp sağlamadığı ortaya konulmaya çalışılmıştır.

\section{MATERYAL VE METOT}

Araştırmanın ana materyalini YTÜ Mimarlık Fakültesi Mimarlık Bölümü 2019-2020 Güz ve Bahar yarıyılı Mimarlıkta Peyzaj Tasarımı dersini alan 2. 3. ve 4. sınıf öğrencileri oluşturmaktadır. Derse kayıtlı 85 öğrenci yapılan araştırma ile ilgili ankete katılmışlardır. Mimarlık bölümü öğrencilerinin almış oldukları Mimarlıkta Peyzaj Tasarımı dersinin işleyişi konusundaki düşüncelerini ortaya koyabilmek için öğrencilere açık ve kapalı uçlu sorular sorulmuştur. 
Açık uçlu sorular evet/hayır olarak cevaplanamayan ya da belli seçeneklerden oluşmayan, katılımcıların duygu ve düşüncelerini belirlemeyi amaçlayan klasik sorulardır. Katılımcılara kendi ifadeleriyle soruyu cevaplama olanağ1 vererek, onu sınırlandırmazlar. Sorunun cevaplarına ilişkin bir öngörü bulunmadığından, olası cevap seçenekleri yer almaz. Tüm cevaplar cevaplayıcıya bırakılmıştır (Yücedağ, 1993).

Yapılandırılmamış sorular olarak da isimlendirebileceğimiz açık uçlu soruların cevaplandırılması süresi kapalı uçlu sorulara verilen cevaplama süresinden uzun sürmüştür. Açık uçlu sorular yorumlama, listeleme ve doldurmak olmak üzere üç grupta hazırlanabilir. Bu araştırmada açık uçlu sorular yorumlama soruları şeklinde hazırlanmış olup öğrencilerin sorulan sorular hakkında daha fazla ayrıntılı ve tarafsız cevap vermelerinin sağlanması amaçlanmıştır.

Açık uçlu soruların cevapları içerik analiziyle analiz edilerek kategoriler oluşturulabilir; ancak bunlar sayısal verilere dökülerek istatistiki yöntemlerle analiz edilmek istendiğinde bu zor olabilmektedir (Tuckman, 1991). Bu araştırmada açık uçlu sorular tek tek okunarak analiz edilmiştir.

Öğrencilerin sorulara özgürce yanıt verebilmelerinin sağlanması amacıyla aşağıdaki açık uçlu sorular tercih edilerek sorulmuştur.

Vaziyet planı ve peyzaj tasarımının mimari projelerinizin okunurluğu açısından ne kadar önemli olduğunu düşünüyorsunuz?

Mimarlıkta Peyzaj Tasarımı dersinin mimari projelerinize katkı sağladığını düşünüyor musunuz?

Mimarlıkta Peyzaj Tasarımı dersinin daha etkili olacağını düşündüğünüz anlatım şekli hangisidir?

Şimdiye kadar almış ve çalışmış olduğunuz mimari projelerden yola çıkarak, eğimli arazilerde vaziyet planlarını hazırlarken zorlanıyor musunuz?

Mimari projelerinize yapacağı katkı düşünülerek “Mimarlıkta Peyzaj Tasarımı” dersi hangi sene ve dönemde verilmelidir?

Almış olduğunuz farklı konulardaki mimari projelerinizin peyzaj düzenlemesini yaparken en çok neye dikkat ettiğinizi yazınız. Peyzajda en çok üzerinde durduğunuz tasarımsal alanlar nelerdir?

"Peyzaj” denildiğinde aklınıza gelen ilk kelimeyi yazınız. Yazdığınız ilk kelimeyi öğrendiğiniz peyzajın tanımı içinde değerlendiriniz.

Açık uçlu sorularda öğrencilerin hem bilgisini, düşüncesini hem de yorumunu öğrenmek mümkün olabilmektedir.

Açık uçlu sorularda öğrencilerin vermiş oldukları cevaplarının değerlendirilmesinde önemli olan öğrencilerin öğrenmiş oldukları bilginin yeterli olup olmadığı ve bilgilerini uygulamaya geçtikleri zaman kullanmada ne kadar başarılı olacaklarını görmektir.

Kapalı uçlu soruların değerlendirilmesinde likert yöntemi kullanılarak evet, hayır, kısmen, önemli, önemli değil, hiç önemli değil ve kararsızım cevapları yer almıştır. Anket sorularının analiz edilmesinde SPSS programı kullanılmıştır. Verilerin frekans değerlerine göre yüzdeleri hesaplanmıştır.

Mimarlık bölümü öğrencilerinin vaziyet planının hazırlanmasında göz önünde bulundurulması gereken faktörler sorgulanmış ve öğrencilerden bu faktörlerin önem derecelerine göre sıraya koymaları beklenmiştir. Anket soruları aynı zamanda öğrencilere çizdirilen sörvey ve alan kullanım proje çalışmaları ile desteklenerek açıklanmıştır

Vaziyet planını hazırlarken dikkate aldıkları faktörlere T-testi uygulanmıştır. Uygulanan T-testi sonucunda öğrencilerin vaziyet planlarını hazırlarken en fazla dikkate aldıkları faktör hangisidir ortaya konulmuştur. 


\section{ARAŞTIRMADAN ELDE EDILEN BULGULAR}

Ankete $40 \mathrm{~K}$ ız ve 45 erkek öğrenci katılmıştır.

Vaziyet planı ve peyzaj tasarımının mimari projelerinin okunurluğu açısından ne kadar önemlidir sorusuna öğrencilerin \%82'si çok önemli cevabını verirken \%18'i ise önemli cevabını vermişlerdir.

Mimarlıkta Peyzaj Tasarımı dersinin mimari projelerine katkı sağlayıp sağlamadığı sorusuna öğrencilerin \%97'si evet cevabını verirken \%3’ü ise kısmen cevabını vermiştir. Tasarımda arazinin topoğrafyasının önemli olduğunu vurgulayabilmek için şimdiye kadar almış ve çalışmış olduğunuz mimari projelerden yola çıkarak, eğimli arazilerde vaziyet planlarını hazırlarken zorlanıyor musunuz? Sorusuna öğrencilerin \%76'sı kısmen zorlanıyorum cevabını vermiştir. Mimari projelerine yapacağı katkı düşünülerek "Mimarlıkta Peyzaj Tasarımı” dersi hangi sene ve dönemde verilmelidir sorusuna öğrencilerin \% $\% 1$ 'i dersin 2. sınıfta verilmesinin uygun olacağını ifade etmişlerdir.

Mimarlık bölümünde güz ve bahar dönemlerinde 2+0 seçmeli ders olarak verilen Mimarlıkta Peyzaj Tasarımı dersi teorik bir ders olup dersin işleyişini sözel ve görsel oluşturmaktadır. Mimarlıkta Peyzaj Tasarımı dersinin daha etkili olacağını düşündüğünüz anlatım şekli hangisidir? Sorusuna öğrencilerin \%88'i dersin uygulamalı olarak verilmesi ve ders saatinin de artırılması gerektiğini belirtirken \%12'si dersin sözel ve görsel olarak anlatılmasının yeterli olduğunu söylemişlerdir.

Öğrencilere almış oldukları farklı konulardaki mimari projelerinin peyzaj düzenlemesini yaparken en çok neye dikkat ettikleri ve Peyzajda en çok üzerinde durdukları tasarımsal alanların neler olduğu sorulmuştur. Verilen yanıtların değerlendirilmesinde T-testi uygulanmıştır. Ve T-testi değerlendirmesi sonucunda öğrencilerin (sig (2-tailed): ,000, Mean dif: 1.563) ile arazi-topoğrafya ilişkisi ve (sig (2-tailed): ,000, Mean dif: 2.019) ile de sirkülasyon alanları üzerinde durdukları ortaya çıkmıştır (Tablo 1).

Tablo 1. Öğrencilerin Mimari Projelerinin Peyzaj Düzenlemesini Yaparken En Çok Dikkat Ettikleri ve Peyzajda En Çok Üzerinde Durdukları Tasarımsal Alanlar

\begin{tabular}{|l|c|c|c|c|}
\hline & $\mathbf{t}$ & Sd (df) & Sig (2-tailed) & Mean differance \\
\hline $\begin{array}{l}\text { Arazi-Topoğrafya } \\
\text { ilişkisi }\end{array}$ & 17.692 & 52 &, 000 & 1.563 \\
\hline Açık Otopark & 30.603 & 44 &, 000 & 4.931 \\
\hline Sirkülasyon Alanları & 9.478 & 49 &, 000 & 2.019 \\
\hline Giriş-Çıkış Noktaları & 15.775 & 48 &, 000 & 3.120 \\
\hline $\begin{array}{l}\text { Yumuşak Peyzaj } \\
\text { Elemanları (bitkisel } \\
\text { elemanlar) }\end{array}$ & 24.233 & 45 &, 000 & 3.953 \\
\hline $\begin{array}{l}\text { Sert Peyzaj } \\
\text { Elemanları }\end{array}$ & 28.039 & 44 &, 000 & 5.798 \\
\hline \begin{tabular}{l} 
Suyun Kullanımı \\
\hline
\end{tabular} & 36.355 & 46 &, 000 & 6353 \\
\hline
\end{tabular}

Mimarlıkta Peyzaj Tasarımı dersi kapsamında yapılmış olan anket çalışmasına katılan öğrencilerin cinsiyetlerine göre dağılımları çapraz tablo analizi kullanılarak yapılmıştır. Mimarlıkta peyzaj tasarımı dersinin mimari projelerine katkı sağladığını söyleyen 80 öğrencinin 42'sini erkek öğrenci oluştururken 38'ni ise kız öğrenci oluşturmaktadır (Tablo 2). 
Tablo 2. Mimarlıkta Peyzaj Tasarımı Dersinin Öğrencilerin Mimari Projelerine Olan Katkısı

\begin{tabular}{|l|c|c|c|}
\hline & Evet & Hayir & Kismen \\
\hline K1z & 38 & - & 3 \\
\hline Erkek & 42 & - & $\mathbf{5}$ \\
\hline Toplam & $\mathbf{8 0}$ & - & \\
\hline
\end{tabular}

Öğrencilere açık uçlu soru olarak "Peyzaj” denildiğinde aklınıza gelen ilk kelimeyi yazınız. Sorusu sorulmuştur. Açık uçlu soruya vermiş oldukları cevaplar değerlendirildiğinde: El değmemiş doğal alanlar, doğal ve kültürel elemanlar, bakış açısı içine giren her şey peyzaj tanımı içinde yer almıştır (Tablo 3).

Tablo 3. Öğrencilerin “Peyzaj” Denildiği Zaman Akıllarına Gelen İlk Tanımlar

\begin{tabular}{|l|c|c|}
\hline & Kişi Sayısı & Yüzdesi \\
\hline Doğal ve kültürel elemanlar & 18 & $\% 21$ \\
\hline El değmemiş doğal alanlar & 23 & $\% 27$ \\
\hline Yeşil alanlar & 12 & $\% 14$ \\
\hline Alle & 10 & $\% 12$ \\
\hline Bakış açısı içine giren her şey & 17 & $\% 6$ \\
\hline Ağaç & 5 & $\% 20$ \\
\hline
\end{tabular}

\section{PEYZAJ TASARIM SÜRECI}

Peyzaj, son yirmi yılda artan sayıda mimari projeler için bir metafor veya kavramsal referans olarak kullanılmıştır. Bu olgu, sanatsal, sosyal ve ekolojik kazanımlar için ilginç bir potansiyele sahip önemli bir mimari yenilik gibi görünmektedir. Bu projeleri daha iyi anlayabilmek ve eleştirel olarak gözden geçirebilmek için peyzaj kavramını daha iyi anlamak önemlidir.

Peyzaj Mimarlığında tasarım süreci, tasarım sorularına form veya cevap ararken atılan adımlar veya yaklaşım olarak tanımlanabilir (Lynch ve Hack, 1984).

Tasarım düşüncesi bir kavram olarak kabul edilir ve iş ve teknoloji dahil birçok alanda uygulanır (Lamster, 2010). Tasarım odaklı düşünme, sol beyne yaratıcı bir denge sağlar, problem çözmeye yönelik sayılara dayalı bir yaklaşım, genellikle statik, yenilikçi olmayan çözümler üretme ile ilişkilendirilir (Cross, 2011).

Peyzaj Tasarım sürecinin birçok yönü varken, öğrencinin anlaması için kritik olan iki özellik öne çıkıyor. Birincisi, tasarım süreci doğrusal değildir. Yani, tasarıma yönelik farklı yaklaşımlar genellikle basit yollarla tanımlanırken, bu esas olarak açıklama kolaylığı içindir, gerçek ise tam tersidir (Brett ve Schmitz, 2009).

İkincisi, tasarımcılar tasarım süreci boyunca kararlar aldıkça, bilinçli veya kasıtsız olarak kararlarına kendi değerlerini katmaktan muaf değiller. Bu değerler Peyzaj tasarımın sonucunu etkiler ve bunların varlığı ve etkisinin anlaşılması gerekir. 
Peyzaj Tasarım süreci, Mimarlıkta Peyzaj Tasarımı dersini alan öğrencilerin hazırlamış oldukları sörvey ve alan kullanım örnekleri ile desteklenerek açıklanmıştır. Peyzaj tasarımı 7 aşamadan oluşan bir proje süreci sonunda ortaya çıkar. Peyzaj tasarım sürecini oluşturan aşamalar şekil 1'de verilmiştir (Korkut ve Kiper, 2020).

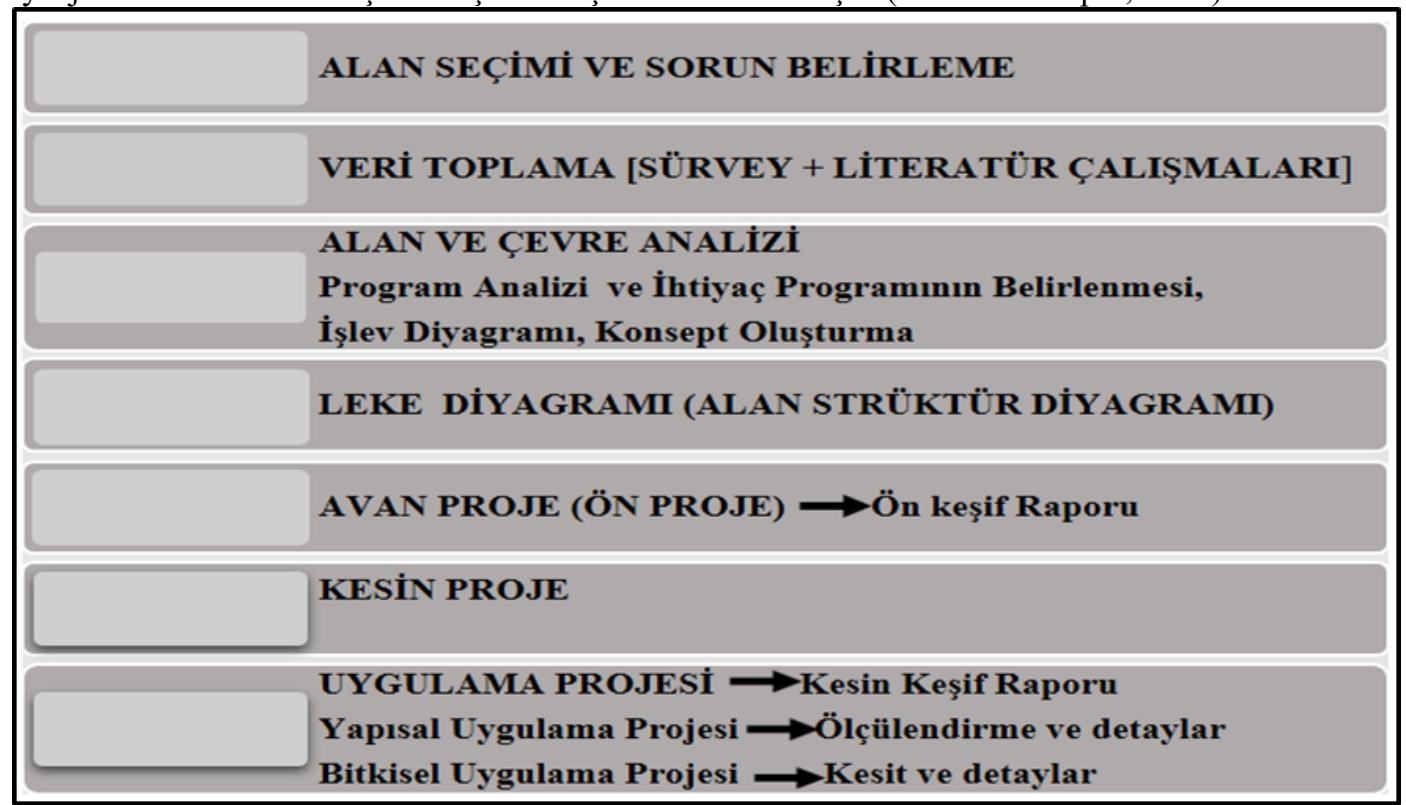

Şekil 1. Peyzaj Tasarım Aşamaları (Korkut ve Kiper, 2020).

\section{1. Alan Seçimi ve Sorun Belirleme}

Mimarlıkta Peyzaj tasarımı dersini alan öğrenciler aynı arazi üzerinde sörvey ve alan kullanım çalıştılar. Çalışma alanı olarak İstanbul'un Anadolu Yakası'nda, Kadıköy ilçesinin Merdivenköy ve Dumlupınar mahallelerinin kesişim noktasında bulunan İstanbul Medeniyet Üniversitesinin arazisi seçilmiştir (Şekil 2).

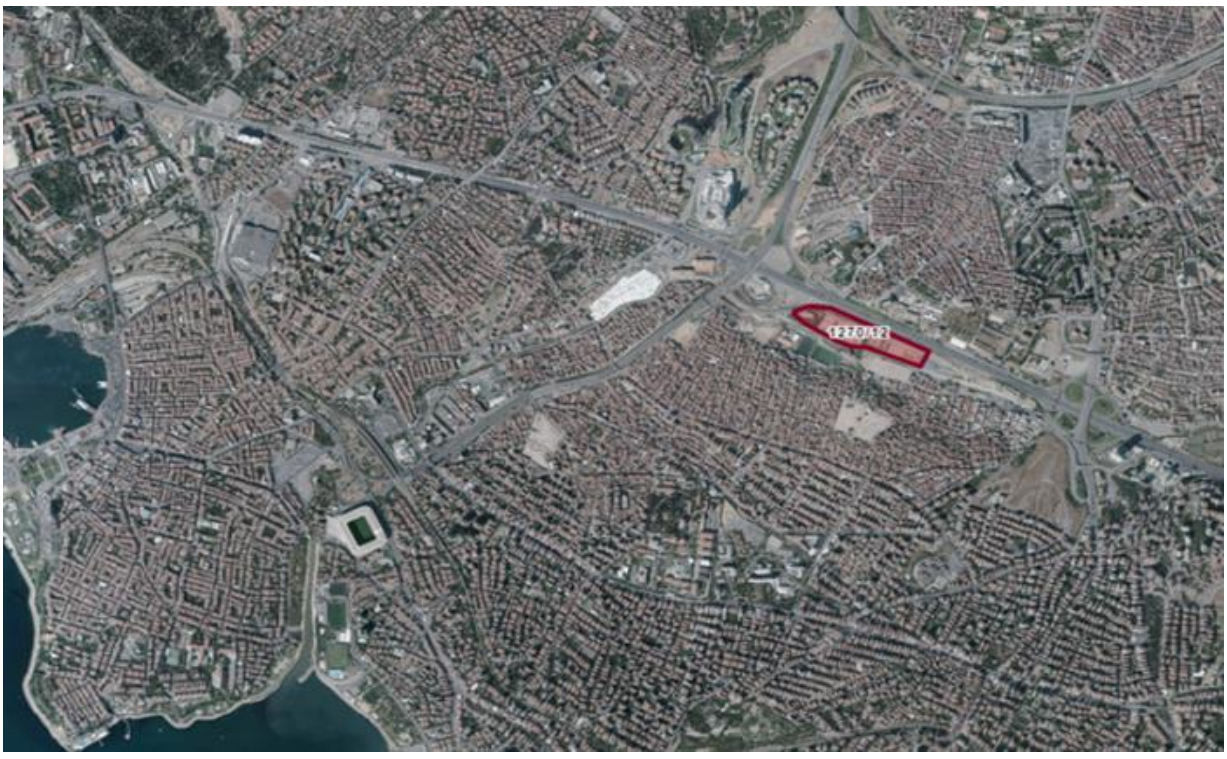

Şekil 2. Çalışma Alanının Konumu (https://parselsorgu.tkgm.gov.tr/) 
Çalışma alanının kuzeyinde Medeniyet Üniversitesi'nin Kuzey Kampüsü ve E-5 Karayolu; kuzeybatısında Metrobüs ve Uzunçayır Kavşağ1; doğusunda M4 Kadıköy- Tavşantepe Metro çıkış kapısı ve güneyinde ise kentsel dönüşüm projelerinin gün geçtikçe artmakta olduğu Fikirtepe mahallesi dönüşüm alanı bulunmaktadır.

\section{2. Sörvey Çalışması}

Mimarlıkta Peyzaj Tasarımı dersini alan öğrencilere öncelikle proje çalışma konusunun amacı ve kapsamı hakkında bilgiler verilmiştir. Öğrenciler gruplara ayrılarak proje alanına gidilerek saha çalışması yapılmıştır. Öğrencilerin peyzaj tasarım sürecini öğrenebilmeleri için sörvey ve alan kullanım (leke) çalışmasına ağırlık verilmiştir.

Sörvey, proje alanının mevcut durumunu, envanterini ortaya koyabilmek için sahada yapılmış olan çalışmadır. Sahada gözlem ve izlenimler yapılır. Mevcut durumu ortaya koyacak detayda fotoğraflar çekilir. Doğal, Algısal ve Kültürel faktörleri oluşturan veriler elde edilerek doğal, algısal ve kültürel faktörler analizi yapılır.

Doğal faktörler analizi yapılırken iklim, topoğrafya, toprak, mevcut bitki örtüsünden oluşan doğal verilerin incelenmesi gerekmektedir. Gürültü, önemli görsel alanlar, iyi ve kötü görünüşler, hâkim manzara verileri kullanılarak algısal faktörler analizi yapılmaktadır.

Kültürel faktörleri ise arazi kullanımı, mevcut yapılar, alt yapı özellikleri, giriş noktası (noktaları), sirkülasyon (alan içi yaya sirkülasyonu, taşıt sirkülasyonu, karayolu sirkülasyonu), otoparklar, tüm yapısal birimler (bina, konut, çeşme, havuz, aydınlatma, merdiven, duvar, vb.), proje alanının yakın çevresi ile olan ilişkisi, yollarla bağlantısı, sınır komşularının belirlenmesi, sınır komşularının kullanım özellikleri, önemli merkezlere olan uzaklık, çevredeki trafik, komşu binaların mimarisi---genel bina yükseklikleri, cephe elemanları, kapı ve pencereler), komşu işlevler, çevrede uygulanan imar yönetmelikleri), alanda varsa mevcut kullanımlar (aktiviteler) ve kullanıcı özellikleri (yaş, sosyokültürel ve sosyo-ekonomik özellikleri vs.), alt yapı ve diğer hizmetler (elektrik, yağmur suyu, kullanma ve içme suyu, kanalizasyon, telefon, havagazı vb) oluşturmaktadır.

Öğrenciler tarafından hazırlanmış olan Sörvey çalışmalarına ilişkin örnekler şekil 3 ve 4'de verilmiştir.

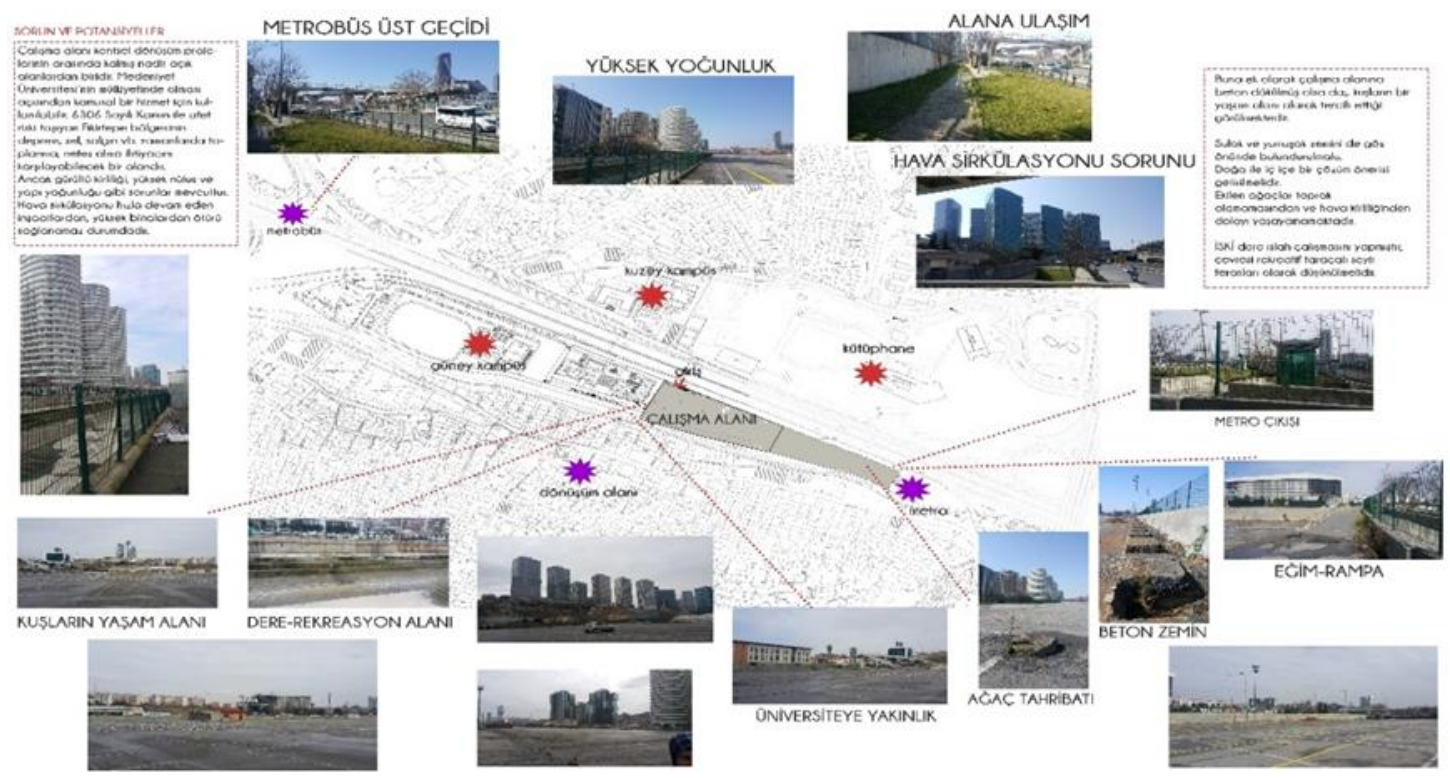

Şekil 3. Proje Çalışma Alanının Sörvey Paftası ( Hazırlayan: Irmak ÇATALCALI) 


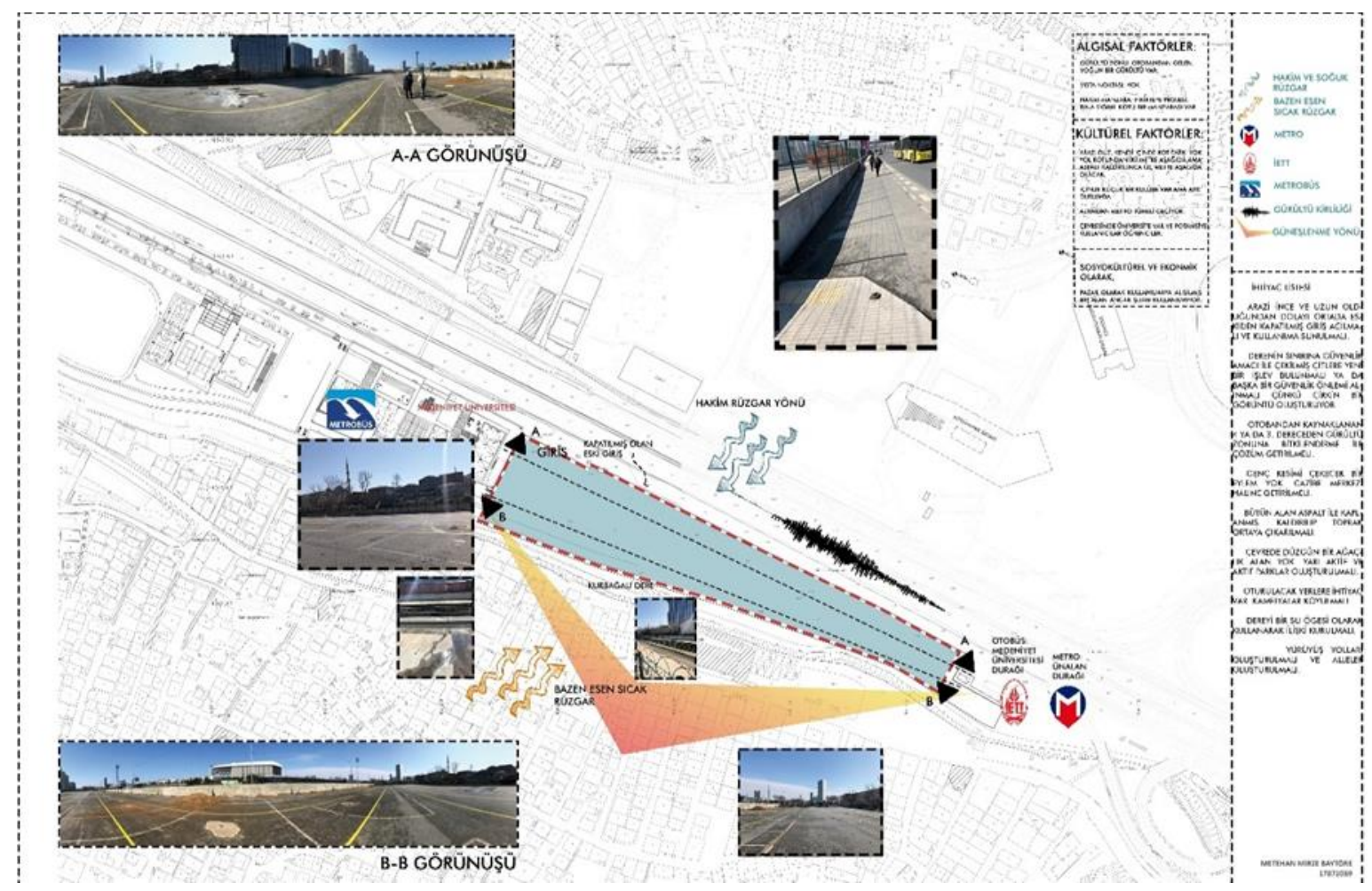

Şekil 4. Proje Çalışma Alanının Sörvey Paftası (Hazırlayan: Metehan Mirze BAYTÖRE)

Alan ve çevre analizleri, sörvey paftası üzerinde ya da ayrı bir pafta üzerinde grafiksel anlatım teknikleri kullanılarak gösterilir.

\section{3. Alan Kullanım (İșlev Diyagramı -Fonksiyon Diyagramı) Çalışmasıı}

Doğal, Algısal ve Kültürel Faktörler analizi sonucunda oluşturulan ihtiyaç programı doğrultusunda öneri alan kullanımları lekeler şeklinde gösterilir. Lekeler biçiminde gösterilen kullanım alanlarının $\mathrm{m} 2$ olarak alansal büyüklükleri, her bir kullanım alanının birbiri ile bağlantısını kuracak şekilde sirkülasyon çözümlerinin yapılması gerekmektedir. İşlev Diyagramı -Fonksiyon Diyagramı grafiksel anlatım tekniklerinin kullanımı ile ölçeksiz olarak hazırlanan yerleşim planıdır. Alan kullanım diyagramının yapılmasının gayesi peyzaj tasarımının dayanağını oluşturan fikir planının yaratılmasıdır.

Öğrenciler tarafından hazırlanmış olan alan kullanım diyagramına yönelik örnekler, şekil 5, 6 ve 7'de verilmiştir. 


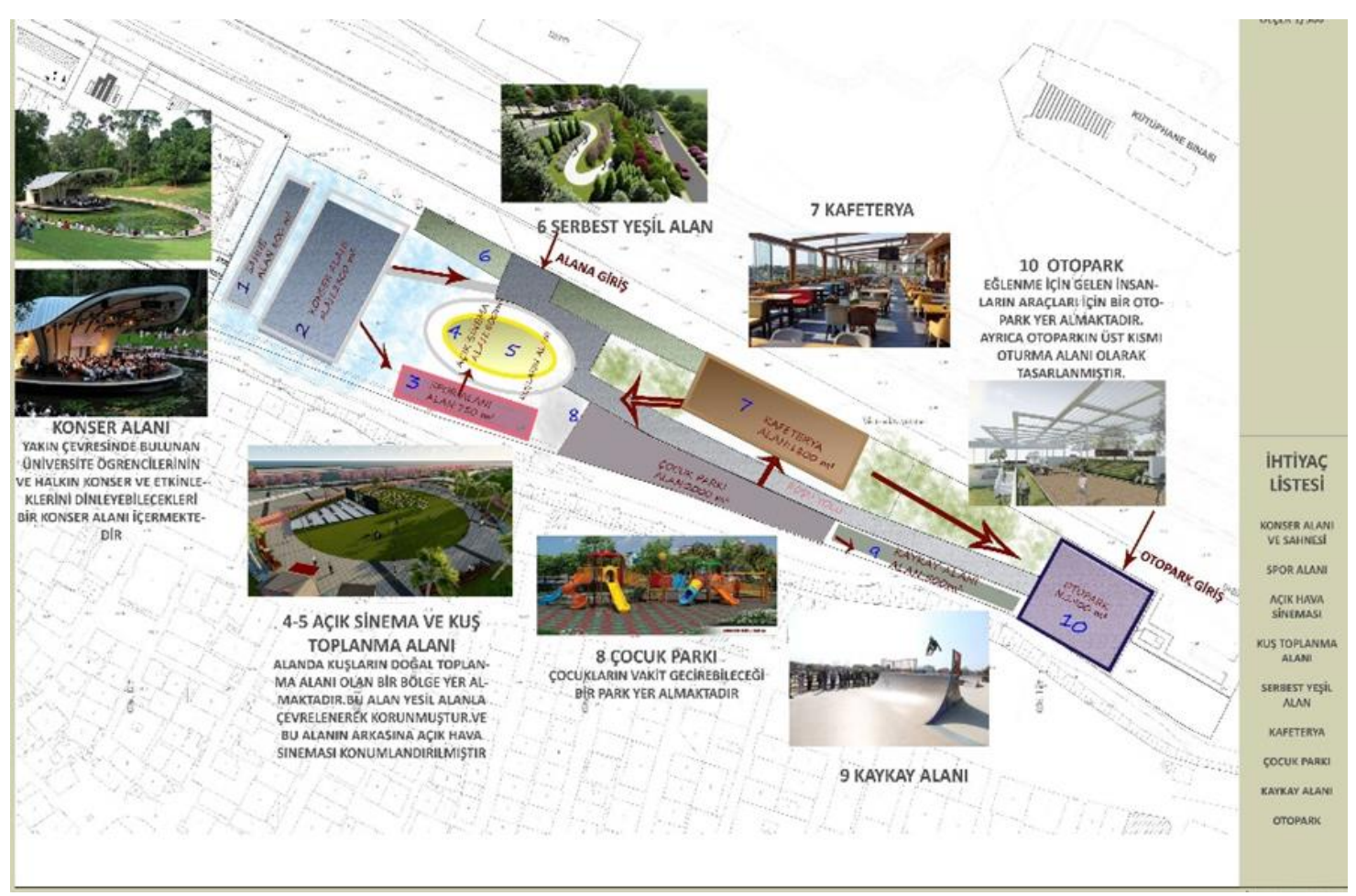

Şekil 5. Proje Çalışma Alanının Alan Kullanım Paftası (Hazırlayan: Gizem ABACI)

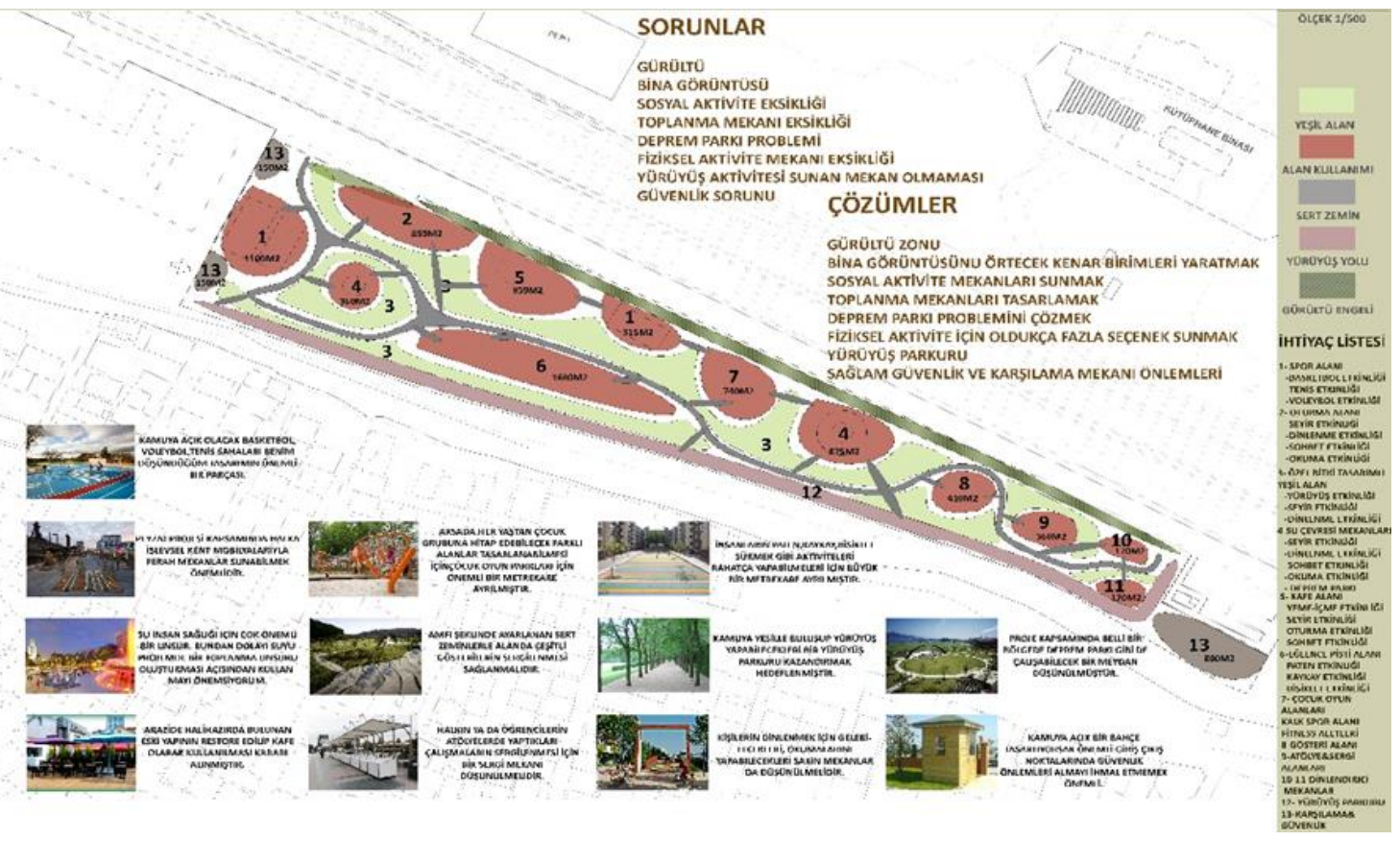

Şekil 6. Proje Çalışma Alanının Alan Kullanım Paftası (Hazırlayan: Hicret YILMAZ) 


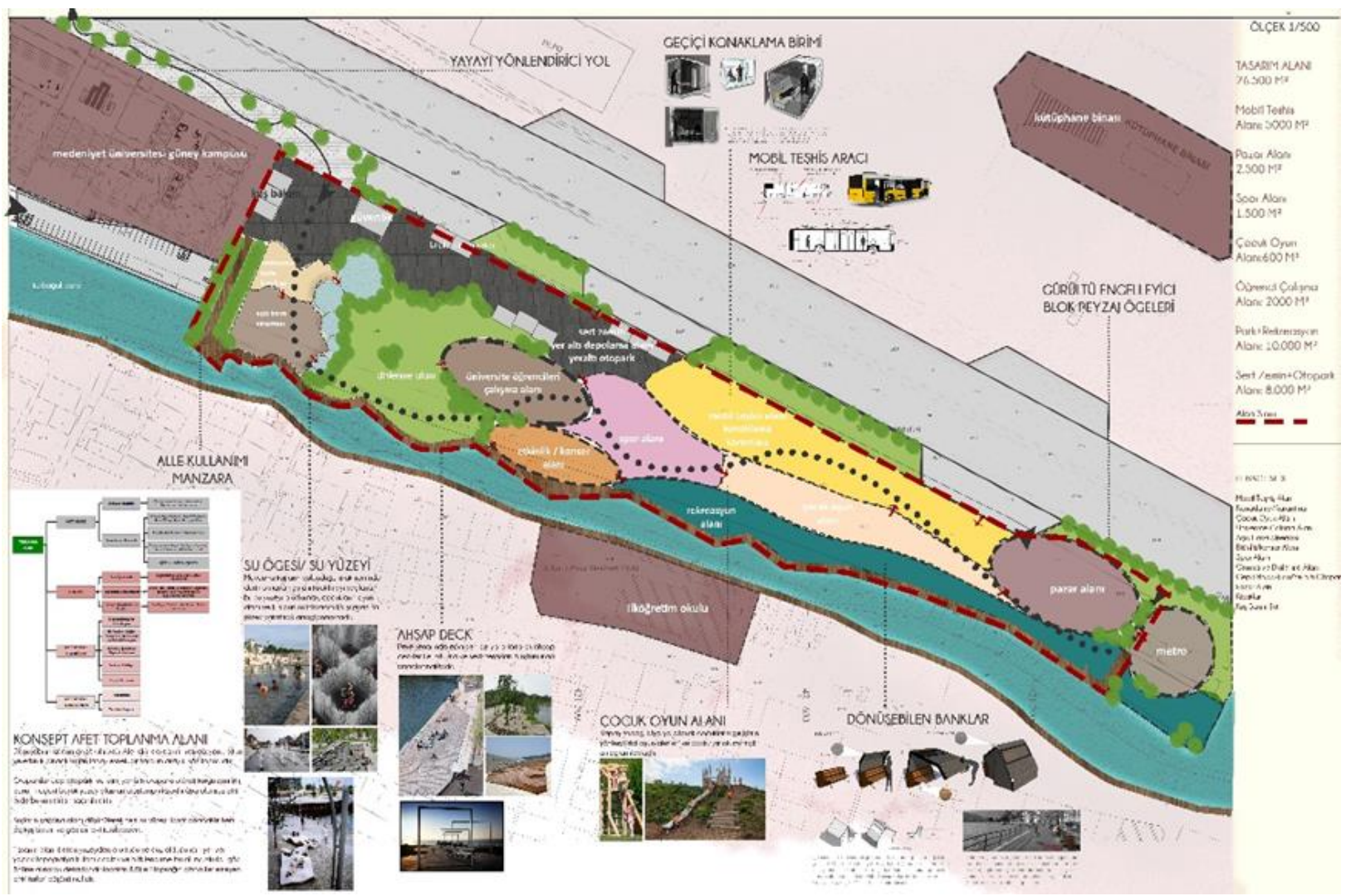

Şekil 7. Proje Çalışma Alanının Alan Kullanım Paftası (Hazırlayan: Irmak ÇATALCALI)

Alan kullanım paftası hazırlanırken ihtiyaç, etkinlik ve mekân ilişkisi kurgulanmalı ve mekânları ifade eden lekelerin olası kullanıc1 sayıları ve $\mathrm{m}^{2}$ 'leri verilmelidir.

Mekânları ifade eden lekeler arasındaki bağlantılar kurgulanmalıdır. Sörvey çalışmasında elde edilen veriler sonucunda alınan alan kullanım kararları ile ihtiyaç listesi ve etkinlik tercihleri ilişkilendirilmelidir.

\section{SONUÇLAR VE TARTIŞMA}

Peyzaj Mimarisi, tüm disiplinlerden bilgi ve yöntemleri kullanarak beşeri bilimler, mühendislik, güzel sanatlar ve doğa bilimleri arasında benzersiz ama aynı zamanda zor bir konuma sahiptir (Fetzer, 2014). Peyzaj mimarlarının sahip olduğu temel yetenek, yani somut ayrıntılar ve hatta küresel peyzaj etkileşimleri arasında geçiş yapma yeteneği mimarlar, sanatçılar, şehir planlamacıları, biyologlar, ekolojistler ve diğer meslektaşları tarafından geliştirilebilecek olandan farklı ve genellikle daha iyi sonuçlar elde etmelerini sağlar (Gazvoda, 2002).

Peyzaj Mimarları aynı zamanda doğayı temsil ederler. Bazı bahçelerde doğanın ideal temsili bir mükemmellik biçimi olduğundan halk, doğanın iyileştirici etkisinin bir peyzaj mimarının görünmez elinin işi olduğunu bile anlamayabilir. Bu durum, Mimarlık ve Şehircilik çalışma programlarında Peyzaj Mimarlığı eğitimini genişletme, mimarlar ve şehir plancıları mesleği için ihtiyaç duyulan çeşitlendirilmiş bilgi gereksinimlerini dengeleme ve uyumlaştırma iddiasını doğrulamaktadır. 
Bersin (2004) tarafından yapılmış olan çalışmada; "hem uygulamalı hem de teorik olarak dersin bir arada yapılmış olması öğrenciler için verimli bir eğitim modeli” olduğu belirtilmiştir. Yapılan bu araştırmada öğrencilerin \% 88'inin dersin uygulamalı olarak verilmesi ve ders saatinin de artırılması gerektiğini ve böylece Mimarlıkta Peyzaj Tasarımı dersinin daha etkili olacağı sonucunu ortaya çıkarmıştır.

Karmanov ve Hamel (2009) yaptıkları bir çalışmada peyzaj mimarlı̆̆ ve mimarlık öğrencilerinin 12 tasarım bahçesinin değerlendirmelerindeki benzerlikleri ve farklılıkları araştırmıştır. Dört bahçenin değerlendirilmesinde iki grup arasında önemli farklılıklar olduğu ortaya çıkmıştır. Öte yandan tasarım, analitik akıl yürütme, sezgi ve yaratıcı ifade dâhil ancak bunlarla sınırlı olmamak üzere çeşitli becerileri içeren çok boyutlu bir faaliyettir. Mimarlık süreci ile peyzaj mimarisi arasında bir boşluk vardır. Mimari tasarım sürecinde çevreye yaklaşım, ya erken aşamalardan itibaren tasarım sürecinde peyzajı bilinçaltı olarak dikkate almak yada tasarım sürecinde peyzajı bilinçli olarak ele almak şeklinde olmaktadır.

Mimarlık bölümü öğrencileri için temel tasarım, iletişim teknikleri, mimari tasarım ve atölye çalışmaları öğrenilmesi gereken en önemli ders gruplarındadır. Mimarlık bölümü ögrencilerinin temel derslerini pekiştirmeleri için farklı disiplinlerden dersleri de almaları gerekmektedir.

YTÜ Mimarlık Fakültesi Mimarlık Bölümünde verilmekte olan Mimarlıkta Peyzaj Tasarımı dersini alan öğrencilerin \%97'sinin anket sorularına vermiş oldukları cevaplarında Mimarlıkta Peyzaj Tasarımı dersinin mimari projelerine katkı sağladığını ortaya çıkarmıştır.

Mimarlık, Şehir ve Bölge Planlama müfredatlarında Peyzaj Mimarlığı ve Peyzaj Tasarım programlarına yönelik derslere ya hiç yer verilmediği ya da çok az yer verildiği görülmektedir. Mimarlar ve Şehir Plancıların binalar ve onların arazileri, peyzajları ve çevre arasındaki karmaşık ilişkileri anlama konusundaki yeterliliklerini sınırlandırmaktadır. Peyzaj Tasarımı ağırlıklı dersler, mimarların ve şehir plancıların eğitimleri için çok önemlidir. Mimarlık, Şehir ve Bölge Planlama müfredatlarında Peyzaj Mimarlığı ve Peyzaj Tasarımına yönelik derslere eğitim süreci içinde yere verebilmek için alt yapının oluşturulması gerekmektedir. Peyzaj Tasarımına yönelik dersler Mimarlık öğrencilerine yapıların dışındaki mekân düzenlemesi ile ilgili bilgileri aktararak bu konudaki becerilerini mimari tasarımlarına yansıtmalarını sağlamaktadır. Mimarlık bölümü öğrencileri Peyzaj tasarımı ilkelerini kullanabilme becerisini kazanırken aynı zamanda Peyzaj ve mekân organizasyonu ilişkisini kurabilme becerisine sahip olacaklardır. Peyzaj Tasarımına etki eden faktörleri irdeleyebilme becerisini kazanarak Peyzaj Tasarımı-Mimari Tasarım ilişkisini kurabilme ve Küçük ölçekli bir peyzaj projesi hazırlayabilme yetisi elde etmiş olacaklardır.

Peyzaj tasarım sürecini karar verme süreci olarak kabul ettiğimizde öğrencilerin doğal, algısal ve kültürel faktörlerin analizini en doğru şekilde öğrenerek tasarım sürecini en iyi şekilde analiz etmeleri sağlanmalıdır. Çünkü Peyzaj tasarımı, dış mekânların kullanıcıları için rahat, kullanışlı ve anlamlı hale getirilmesi için yaratıcı bir süreçtir. Mimarlık ögrencilerini, yapıları ve açık alanları bütünleştirme açısından inşa edilen formun yerine ve yerleşimine duyarlı hale getirmek Peyzaj tasarımı konusunun amaçlarından biridir. Yapılan bu araştırmanın sonucunda öğrencilerin derste çizdikleri projeler ve öğrendikleri Peyzaj Mimarlı̆̆ı kavramları sayesinde kendi alanlarını geliştirdikleri, bu anlamda Peyzaj Mimarlığı Eğitiminin Mimarlık öğrencileri için faydalı ve gerekli olduğu ortaya çıkmıştır. Peyzaj Mimarlığı Eğitimi verilmeyen Mimarlık Bölümlerinin ders programlarına Peyzaj Mimarlığı derslerinin dahil edilmesi yerinde bir karar olacaktır.

\section{Etik Standart ile Uyumluluk}

Çıkar Çatışması: Tek yazarlıdır.

Etik Kurul İzni: Bu çalışma için etik kurul iznine gerek yoktur.

Finansal Destek: Yoktur.

\section{Teşekkür:}




\section{KAYNAKÇA}

Austerlitz, N., Aravot, I., Ben-Ze'ev, A., (2002). Emotional phenomena and the student-instructor relationships. Landscape and Urban Planning, 60 (2002), 105-115.

Bersin, J. (2004). The Blended Learning Book: Best Practices, Proven Methodologies and Lessons Learned, Pfeiffer and Co.

Boyer, E., Mitgang, L., (1996). Building Community: A New Future for Architectural Education and Practice. London:Jossey- Bass Inc Pub.

Brett, D. L., Schmitz, A. (2009). Real estate market analysis: methods and case studies (2nd ed.), Washington, DC: Urban Land Institute.

Bruns, D., Ortacesme, V., Stiles, R., de Vries, J., Holden, R., Jorgensen, K. (2010). ECLAS Guidance on Landscape Architecture Education. The Tuning Project ECLAS - LE:NOTRE. Tuning Landscape Architecture Education in Europe, Report, Version 26, LE:NOTRE project of ECLAS.

Cross, Nigel. (2011). Design Thinking: Understanding How Designers Think and Work. Oxford: Berg Publishers.

Fetzer, E. (2014). Knowledge Building in Landscape Architecture. Kassel University Press, ISBN: 978-3-86219-5480 .

Gazvoda, D. (2002). Characteristics of modern landscape architecture and its education. Landscape and Urban Planning, 60 (2), 117-133.

Gül, A. (2015). Peyzaj Mimarlı̆̆ı Disiplini ve Mimarlık Bilimi İlişkisi.

[http://www.plantdergisi.com/atila-gul/peyzaj-mimarligi-disiplini-ve-mimarlik-bilimi-iliskisi.html].

Hunziker, M., Buchecker, M., Hartig, T. (2007). Space and Place - Two Aspects of the Human-landscape Relationship. In: Kienast F., Wildi O., Ghosh S. (eds) A Changing World. Landscape Series, Vol 8. Springer, Dordrecht, 47-62.

Karmanov, D., Hamel, R., (2009). Evaluations of Design Gardens by Students of Landscape Architecture and Nondesign Students: A Comparative Study. Landscape Research, 4 (34). 457 - 479.

Kent, R. L., (1997). LA/Pictionary: Students Create Games to Teach and Learn Landscape Architecture. Journal of Architectural Education, 50(4), 265-270.

Korkut, A., Kiper, T., (2020). Mimarlıkta Peyzaj Tasarımı, Bölüm adı: Kentsel alanlarda peyzaj tasarım süreci, NOBEL Akademik Yayıncılık, Editör: Yıldız AKSOY, Basım sayısı:1, ISBN:978-605-033-138-7.

Lamster, M. (2010). Business philosophy? On the virtues - and perils - of design thinking. Architect (Washington, DC), 99 (7), 36-37.

Lynch, K., Hack, G. (1984)..Site Planning (3rd ed.). Cambridge, Massachusetts: The MIT Press.

Tuckman, B.W. (1991). Evaluating the alternative to multiple-choice testing for teachers. Contemporary education, 62 (4), 299-300.

Yücedağ, A. (1993). Anket geliştirilmesi ve uygulanması. Ankara Üniversitesi Eğitim Bilimleri Fakültesi Dergisi, 26(2), 443-454.

\section{Internet Kaynakları}

https://parselsorgu.tkgm.gov.tr/ 